Jaromir Brejdak

\title{
HERMENEUTYCZNA PERSPEKTYWA FILOZOFII POLITYKI
}

Andrzej Przyłębski, Dlaczego Polska jest wartością. Wprowadzenie do hermeneutycznej filozofii polityki,

Wydawnictwo Poznańskie, Poznań 2013.

Książka profesora Andrzeja Przyłębskiego wpisuje się w jego szeroko zakrojony cykl prac poświęconych hermeneutyce . I tak po książce poświęconej hermeneutycznemu ujęciu etyki - Etyka w świetle hermeneutyki ${ }^{1}$ - czas na hermeneutyczne ujęcie polityki czy filozofii politycznej. Przy czym już samo rozumienie hermeneutyki zasługuje tu na uwagę, gdyż autor wprowadza wyraźną linią demarkacyjną pomiędzy hermeneutyką a postmodernizmem czy hermeneutyką a dekonstrukcjonizmem, poświęcając tym rozróżnieniom rozdział drugi swej ksiązki i wywodząc tożsamość hermeneutyki z jej klasycznych, to jest zarówno antycznych, jak i niemieckich korzeni: wpływu transcendentalnej filozofii Kanta, Fichteańskiej filozofii wolności czy Heglowskiej teorii nowoczesnego społeczeństwa. Ta „klasyczno-pozytywna" interpretacja hermeneutyki (Kant, Fichte, Hegel) ustawia myślicieli takich jak Nietzsche w opozycji do siebie, przyjmując, niejako niezauważenie, postmodernistyczną interpretację Nietzscheańskiej filozofii. Owa negatywność Nietzscheańskiej filozofii jest, jak wielokrotnie wykazywałem, negatywnością metodyczną czy wręcz majeutyczną ${ }^{2}$. Rola Nietzschego $\mathrm{w}$ rozwoju hermeneutyki jest nie do przecenienia, nie tylko dlatego, iż ukazał on interpretacyjność egzystencji jako warunek tożsamości

${ }^{1}$ Zob. A. Przyłębski, Etyka w świetle hermeneutyki, Warszawa 2010.

${ }^{2}$ Są także inne możliwości odczytywania myśli Nietzschego; por. np. J. Brejdak, Ewangelia Zaratustry, Warszawa 2014, gdzie ukazuję pokrewieństwo przekazu Jezusa i Nietzscheańskiego Zaratustry. 
człowieka, co w następstwie tego wyróżnienia interpretacyjności przejęli zarówno Dilthey w swojej kategorii znaczenia (Bedeutung), jak i Heidegger w kategorii projektu (Entwurf) ${ }^{3}$, ale też dlatego, że jako pierwszy wprowadził on do słownika filozoficznego określenie sensu życia, na co zwracał uwagę Volkert Gerhardt4. Oznaczo to zmianę paradygmatu rozumienia ludzkiego działania, polegającą na zamianie telos na logos, zamianie projektu teologicznego $\mathrm{w}$ sposobach rozumienia ludzkiego działania na projekt nowy, którego główną siłą sprawczą staje się sens i jego poszukiwanie. W części trzeciej autor Wprowadzenia do filozofii polityki z właściwą hermeneucie troską o tradycję ukazuje hermeneutykę jako archeologię sensu czy sensów, które sendymentują coraz głębiej, stając się coraz bardziej oczywiste, a przez to coraz mniej widoczne, co autor zarówno w pouczający, jak i zabawny sposób egzemplifikuje przykładem zaczerpniętym od Piotra Zarębskiego, a dotyczącym szerokości odstępu szyn kolejowych w Ameryce (cztery stopy oraz osiem i pół cala), którego genealogia sięga czasów Imperium Rzymskiego i obecności Legionów na terenie Anglii.

Indywidualną, jak i zbiorową tożsamość może odnowić jedynie powrót do źródeł siły (Taylor) 5 , źródeł sensu wspomaganych poprzez wychowanie (Bildung). Wychowanie nie oznacza tutaj przyjęcia abstrakcyjnych reguł postępowania, lecz ich interioryzację czy ucieleśnienie za sprawą wzorców osobowych. Autor pisze, iż:

etyka hermeneutyczna nie pragnie ani spekulatywnego ugruntowania moralności, ani wytworzenia nowego systemu etyki normatywnej. Odwołuje się raczej do etosu obecnego jeszcze w przestrzeni publicznej, który chce zachować i rozwijać. To drugie jest niemożliwe bez szlifowania etycznej władzy sądzenia, której efektem jest sumienie, „wola-posiadania-sumienia”. Dla tego pierwszego bardzo ważna jest edukacja etyczna [...]. Pamiętają o tym wszystkie kultury za wyjątkiem europejskiej, która na naszych oczach rezygnuje ze swego kulturowego, w tym: etycznego, dziedzictwa. Porzucenie idei wychowania w szkole na rzecz przekazywania, „obiektywnej wiedzy naukowej" oraz przerzucenie tego wychowania na rodziców to najlepsze dowody na destrukcyjną siłę tej zgubnej tendencji ${ }^{6}$.

Pojęcie wychowania (Bildung) w swojej etymologii niemieckiej oznacza źródłowo tworzenie i formowanie, ukazując tym samy majeutyczny swój

\footnotetext{
3 Pisałem o tym w książce Philosophia crucis. Heideggers Beschäftigung mit dem Apostel Paulus, Frankfurt am Main 1996. Zobacz także: J. Brejdak, Stowo i czas. Problem rozumienia Innego whermeneutyce i w teorii systemu, Szczecin 2004.

4 V. Gerhardt, Friedrich Nietzsche, München 2006, s. 67.

${ }^{5}$ Por. J. Brejdak, Tożsamość a realizm wartości. Materialna etyka wartości, „Kwartalnik Filozoficzny" 2008, z. 3, t. 36 .

${ }^{6}$ A. Przyłębski, op. cit., s. 91-92.
} 
wymiar, polegający na umiejętnym przyswojeniu i zinterioryzowaniu przekazywanej wiedzy, choć trafniej jest w tym majeutycznym kontekście mówić o przyswajaniu sposobów bycia, umożliwiającym następnie samodzielny wzrost egzystencjalny. Filozofia, która chce być wiarygodna, musi tematyzować konkretne sposoby bycia, dokonując niejako reduplikacji słowa i czynu, co $\mathrm{w}$ innym miejscu określiłem mianem majeutycznego zwrotu $\mathrm{w}$ fenomenologii 7 , odwołując się do przywoływanego tu Heideggera (teoria znaczenia poprzez dokonywanie Vollzugstheorie der Bedeutung), jak i Schelera (osoba jako akt, którego rozumienie czy uczestnictwo w bycie musi implikować zdwojenie aktu, na czym opiera się Schelerowska teoria działania wzorca osobowego czy wzrostu ducha). Max Scheler jest autorem, którego brak w omawianym tu, jakże ważnym i interesującym kontekście hermeneutycznej filozofii polityki odczuwam chyba najbardziej. Przyczyną jest nie tylko uprawianie przez Schelera pewnej hermeneutyki w jej najgłębszym aksjologicznym wymiarze, który określiłem mianem hermeneutyki uczuć ${ }^{8}$, nie jest nią także jego kategoria funkcjonalizacji, uprzedzająca Heideggerowską kategorię przedrozumienia czy Gadamerowską kategorię przedsądów, czyli sendymenacji ducha, tworzącej szeroko pojęty horyzont naszego spotkania z rzeczywistością, lecz na wskroś polityczny i wspólnotowy wymiar osoby obecny w jego filozofii ${ }^{9}$. Person i Polis to wielki i główny, jak sądzę, temat tej bogatej myśli.

W rozdziale „Naród jak wspólnota językowa” Przyłębski w bardzo przekonujący sposób ukazuje tożsamościowotwórczą rolę języka. Język jest tu ujmowany jako ontologiczne schronienie - dom danego narodu czy danej jednostki. Język w ujęciu hermeneutycznym Heideggera czy Gadamera jest domem z oknami, przez które oglądamy świat. Ewolucja języka za sprawą narodowych wieszczy, geniuszy języka, którymi są najczęściej poeci, inicjuje zarazem ewolucję danego narodu. Z kolei rozdział "Tradycja jako spichlerz narodu" ukazuje nośność takich hermeneutycznych, a w szczególności Gadamerowskich, pojęć, jak tradycja czy autorytet. Stwierdza w nim autor: „Historia, tradycja, kultura - oto główne pojęcia decydujące o trwaniu i spo-

7 J. Bredak, Majeutyczny zwrot w fenomenologii, „Fenomenologia” 2011, nr 9.

8 J. Brejdak, Max Scheler - hermeneutyka uczuć, [w:] idem, Stowo i czas, op. cit.; oraz: Idem, Hermeneutyka uczuć. Schelerowskie podstawy rozumienia człowieka, „Kwartalnik Filozoficzny” 2004, z. 3, t. XXXII.

9 Piszę o tym w tekście Polityczny personalizm Schelera (tekst przygotowany na XIV Konferencję Polskiego Towarzystwa Fenomenologicznego - „Fenomenologia a nauki społeczne”, Warszawa 28-29 listopada 2014 r.), czy wcześniej w: Fenomenologiczne paradygmaty uzasadniania wspólnoty, [w:] Intersubiektywność, red. P. Makowski, Kraków 2012. 
istości wspólnoty komunikacyjnej zwanej narodem. Filozofia hermeneutyczna nie zapoznaje tego ani nie przechodzi obok tego obojętnie"10.

Rozdział piąty, zatytułowany „Hermeneutyczna filozofia polityki. Prolegomena", ukazuje stanowisko hermeneutyki wobec ideologii liberalizmu oraz jej stosunek do komunitarianizmu i republikanizmu. Cechą, która łączy te dwa ostatnie z hermeneutyką, okazuje się źródłowa wspólnotowość jednostek, ich afektywna oraz aksjologiczna więź.

Praca Andrzeja Przyłębskiego wpisuje się zatem w nurt hermeneutyki politycznej, pojawiający się $\mathrm{w}$ naszym pejzażu filozoficznym dość rzadko. Z całą pewnością do nurtu tego zaliczyć należy prace Jacka Bartyzela, kierującego specjalnie dla tego celu powołaną katedrą hermeneutyki politycznej w Toruniu, czy książkę Andrzeja Gniazdowskiego Tradycjonalizm Josepha de Maistre'a jako hermeneutyka polityczna (Warszawa 1996).

Wartość hermeneutycznej filozofii politycznej w ujęciu Andrzeja Przyłębskiego zasługuje na uwagę także i z tego powodu, że ukazuje wagę fundamentalnych kategorii hermeneutycznych, takich jak wspomniane już wcześniej dziedzictwo, wykształcenie czy język, które pełnią niezbywalną rolę w życiu każdej wspólnoty narodowej czy kulturowej. Próba aplikacji tych abstrakcyjnych skądinąd kategorii do konkretnej sytuacji wspólnotowej, jaką znajdujemy w książce Dlaczego Polska jest wartością. Wprowadzenie do hermeneutycznej filozofii polityki, jest próbą zasługującą bezsprzecznie na zainteresowanie i lekturę czytelnika.

${ }^{10}$ A. Przyłębski, op. cit., s. 119. 